\title{
Extraction of bioactive moieties of Cupressus arizonica and Cupressus sempervirens wood knots
}

\author{
Ali Abdulkhani ${ }^{1}$, Akram Sedaghat ${ }^{1}$, Peyman Alizadeh ${ }^{2}$ and Lope G. Tabil ${ }^{2, *}$ \\ ${ }^{1}$ Department of Wood and Paper Science and Technology, Faculty of Natural Resources, Campus of Agriculture and \\ Natural Resources, University of Tehran, P.O. Box 4111, Karaj 31587-77871, Iran \\ ${ }^{2}$ Department of Chemical and Biological Engineering, University of Saskatchewan, Saskatoon, SK, S7N5A9, Canada \\ *Corresponding Author: lope.tabil@usask.ca
}

\begin{abstract}
This research was aimed to determine the hydrophilic bioactive extractives of Arizona cypress. The extractives of Arizona cypress were isolated and characterized by gas chromatography-mass spectrometry (GC-MS). Hydrophilic compounds of the extractives were mildly isolated by soaking the wood flour in ethanol: water $(9: 1 \mathrm{v} / \mathrm{v})$ solution followed by $n$-hexane extraction to remove the lipophilic moieties. Raw extract of Arizona cypress was further purified to isolate the bioactive phenols using dichloromethane-ethanol in a solvent-solvent system and precipitation with potassium acetate. The bioactivity of the hydrophilic extracts of Cupressus arizonica was determined and compared with the raw hydrophilic extractives of Cupressus sempervirens and Picea excelsa. The total phenol content was determined according to the folinciocalteu method. The antioxidant capacity was determined by iron (II) chelating activity and the 2,2-diphenyl-1picrylhydrazyl (DPPH) free radical scavenging assay. From the GC/MS analysis, different amounts of bioactive moieties, including matairesinol (MAT), curcumin, dienestrol, arctigenin (ARC) and sescoisolariciresinol (SEC), were found in the extract of C. arizonica wood knots. Comparative evaluation of the total phenolics by folin-ciocalteu analysis showed that extraction by simple soaking could precisely indicate the quantity of phenolic compounds in the extracts. The antioxidant activity of extracts indicated by DPPH radical scavenging and iron (II) chelating capacity showed that the antioxidant activity is dependent on the amount and category of bioactive phenols in the extracts.
\end{abstract}

\section{KEYWORDS}

bioactive phenols, Arizona cypress, wood knot, antioxidant activity, extractives

\section{RÉSUMÉ}

Cette recherche avait pour but de déterminer les matières extractibles hydrophiles bioactives du cyprès de l'Arizona. Les matières extractibles du cyprès de l'Arizona ont été isolées et caractérisées par chromatographie en phase gazeuse et spectrométrie de masse (CG-SM). Les composés hydrophiles des matières extractives ont été isolés en trempant la farine de bois dans une solution d'éthanol et d'eau $(9: 1 \mathrm{v} / \mathrm{v})$, suivi d'une extraction au n-hexane pour éliminer les fractions lipophiles. L'extrait brut de cyprès de l'Arizona a été purifié davantage pour isoler les phénols bioactifs en utilisant du dichlorométhaneéthanol dans un système solvant-solvant et une précipitation avec de l'acétate de potassium. La bioactivité des extraits hydrophiles du Cupressus arizonica a été évaluée et comparée aux extraits hydrophiles bruts du Cupressus sempervirens et du Picea excelsa. La teneur totale en phénols a été mesurée selon la méthode FolinCiocalteu. La capacité antioxydante a été déterminée par l'activité de chélation du fer (II) et l'analyse de piégeage des radicaux libres 2,2-diphényl-1-picrylhydrazyl (DPPH). D'après l'analyse GC/MS, différentes quantités de fractions bioactives, dont le matairesinol (MAT), la curcumine, le diénestrol, l'arctigénine (ARC) et le sescoisolariciresinol (SEC), ont été trouvées dans l'extrait de nœuds du C. arizonica. L'évaluation comparative des phénols totaux par analyse Folin-Ciocalteu a indiqué que l'extraction par simple trempage permettait de mesurer précisément la quantité de composés phénoliques dans les extraits. L'activité antioxydante des extraits évaluée par le piégeage des radicaux DPPH et la capacité de chélation du fer (II) a montré que cette activité dépend de la quantité et de la catégorie des phénols bioactifs dans les extraits.

\section{MOTS CLÉS}

phénols bioactifs, cyprès de l'Arizona, nœud de bois, activité antioxydante, matières extractibles

\section{CITATION}

Abdulkhani, A., A. Sedaghat, P. Alizadeh and L.G. Tabil. 2020. Extraction of bioactive moieties of Cupressus arizonica and Cupressus sempervirens wood knots. Canadian Biosystems Engineering/Le génie des biosystèmes au Canada 62: 8.18.10. https://doi.org/10.7451/CBE.2020.62.8.1 


\section{INTRODUCTION}

The unavoidable global depletion of fossilized resources and its environmental issues has driven the industrial sector toward developing a sustainable bio-based economy (Langeveld, Dixon, and Jaworski 2010). In this context, the biorefinery is the critical technology in processing biomass, e.g., lignocellulosic, into value-added products, including biofuels, biochemicals, and biomaterials (Bhaskar et al. 2016; Kamm, Schonicke, and Hille 2016). In the pulp and paper industry, a substantial amount of wood knots has to be screened during the pulping process because they have a stiff texture that makes them completely inappropriate for pulp and paper making processes (Zhang et al. 2010; Holmbom et al. 2007). The general process of wood knot screening during the preparation of wood chips in a conceptual biorefinery is presented in Fig. 1. Nevertheless, these bio-wastes contain particular bioactive metabolites, which have important ecological behaviour like natural resistance against insects or fungi or attracting pollinators (Holmbom et al. 2007; Aranda et al. 2018). Wood knots contain up to 100 times more extractives than the surrounding regular wood (Pietarinen et al. 2005a). In general, the pharmaceutical, cosmetic, and nutraceutical industries are more interested in secondary metabolites, including lignans and flavonoids, since these compounds are considered effective antioxidants that are potentially useful for preventing and remediation of certain diseases (da Silva et al. 2005). Therefore, isolating extractives from the wood knot is a convenient way to value-add in first-

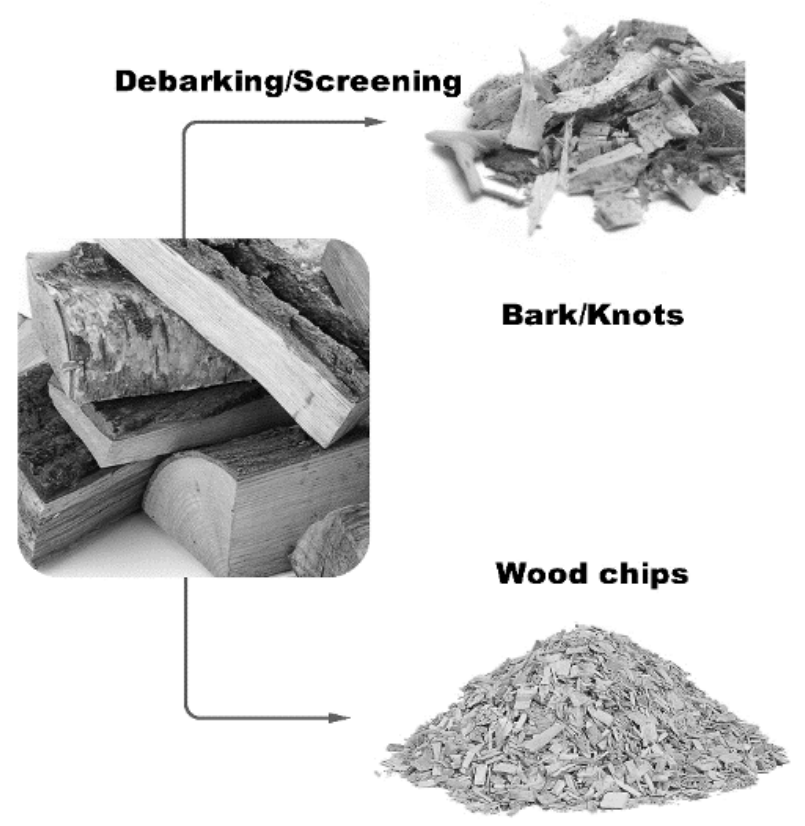

generation biorefinery plants like pulp mills (Sedaghat, Abdolkhani, and Khodaiyan chegini 2015). Lignans from wood extractives have attracted much attention because of their health-promoting effects; they possess antioxidant, antitumor, and antiviral properties (Wijayanto et al. 2015). Lignan is a generic name for the family of compounds derived from two $\beta-\beta$ linked $\mathrm{C}_{6} \mathrm{C}_{3}$ units. Conidendrin, 7hydroxymatairesinol (HMR), pinoresinol, and lariciresinol are the most important classes of lignans in different wood species (Miki et al. 1980). Lignans in the Picea abies wood knots are mainly composed of hydroxymatairesinol, which is $65-85 \%$ of the lignans in this species (Willfor et al. 2004). Recent studies extracted and characterized the different bioactive compounds in other wood species and resources (Valette et al. 2017; Liu, Willför, and Xu 2015; Im, Kim, and Kim 2014). During the last decade, the steadily increasing investigations for further, richer and cheaper sources of bioactive phenols were the main objective (Sharma, Pandey, and Lata 2009; Pietarinen, Willför, et al. 2005; Sedaghat, Abdolkhani, and Khodaiyan chegini 2015). Although wood and bark hydrophilic and lipophilic extractives have been studied in many tree species, extractives in wood knot have been analyzed previously only for select softwood species, Araucaria angustifolia, Pinus radiata, Pinus sylvestris, and Picea abies (Peralta et al. 2016; Hillis 1971; Hillis and Inoue 1968; Conde et al. 2014; Jonsson et al. 2011; Sergio et al. 2009; Holmbom et al. 2007; Willfor et al. 2004). However, it has long been commonly known that softwood knots can contain large

Fig. 1. Proposed process of wood biorefinery.

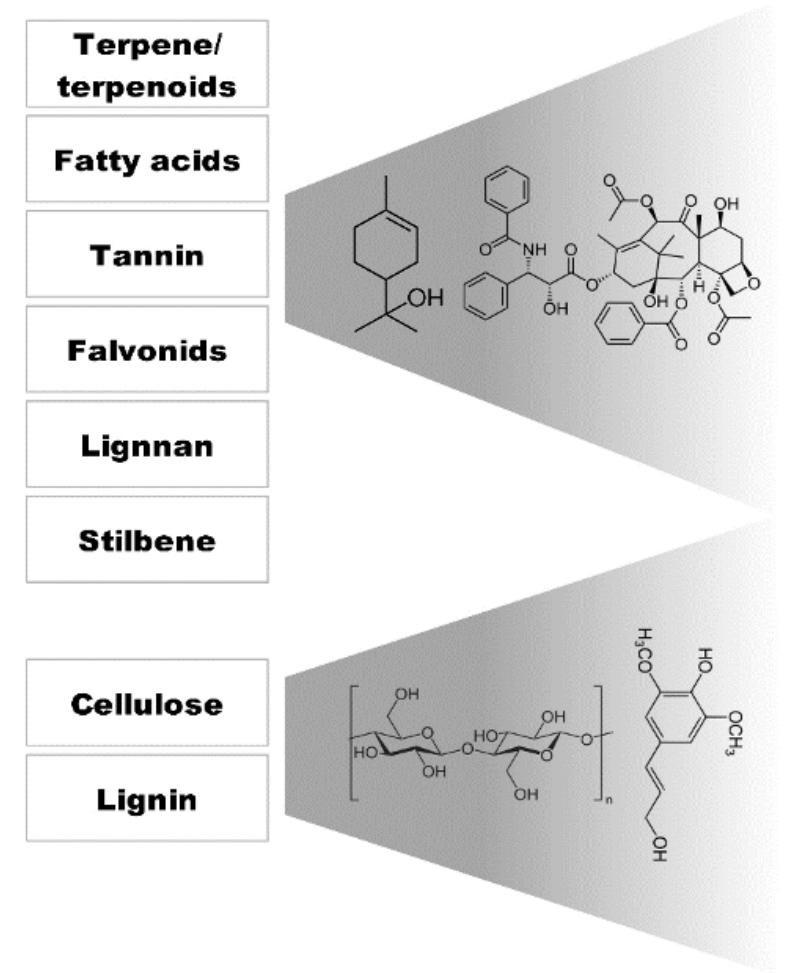


amounts of extractives (Kebbi-Benkeder et al. 2015; Phelan et al. 2009; Holmbom et al. 2007). No systematic studies have yet been reported on the hydrophilic extractives in the wood knot of main cypress family species, including Cupressus arizonica (Arizona cypress) and Cupressus sempervirens (Mediterranean cypress). Both species are among the endemic trees of the vast majority area of the Mediterranean region. They are somewhat drought tolerant, have low water requirements once established, and can withstand the heat of summer.

This study was aimed to extract and purify the bioactive phenols in wood knots of Cupressus arizonica and Cupressus sempervirens. Due to the heat sensitivity of antioxidants, thermal oxidation of bioactive phenols is unavoidable during the extraction. Therefore, this study used a simple immersion of raw material in a solvent at ambient temperature to isolate the lipophilic and hydrophilic compounds. The antioxidant activity of purified lignans was also determined using radical scavenging DPPH and ferrous ion chelating assays and was compared with the phenol activity of Picea excelsa.

\section{MATERIALS AND METHODS}

\section{Extraction}

Arizona cypress (Cupressus arizonica), Mediterranean cypress (Cupressus sempervirens) trees, and Norway spruce (Picea excelsa) trees were supplied from the university forest sites of the University of Tehran (Iran). Wood disks were cut from the logs immediately just after felling. The wood disks were frozen immediately with liquid nitrogen and stored under $-80^{\circ} \mathrm{C}$ until analysis. The knots of wood disks were carefully cut into small pieces with a cutting knife and then suspended into n-hexane to eliminate the lipophilic moieties and successively in $\mathrm{EtOH}: \mathrm{H}_{2} \mathrm{O}(1: 9$; v: v) for $72 \mathrm{~h}$ under ambient temperature to obtain the raw extract. The EtOH: $\mathrm{H}_{2} \mathrm{O}$ solution was evaporated under reduced pressure, and the raw residue was further fractionated after freeze-drying using thin layer chromatography (Wako Pure Chemical Industries, Ltd., Osaka, Japan) with dichloromethane (DCM):ethanol $(10: 1 ; \mathrm{v}: \mathrm{v})$ as a mobile phase to give a phenol-rich fraction (purification with DCM). Also, the bioactive moieties were precipitated by adding potassium acetate to the raw EtOH: $\mathrm{H}_{2} \mathrm{O}$ extract (purification with potassium acetate) (Cosentino et al. 2007).

\section{Determination of total phenol content}

The total polyphenol content (TPC) was determined by spectrophotometry (Uvikon XL, Bio-Tek Instruments, Bad Friedrichshall, Germany) with the Folin- Ciocalteu reagent, using gallic acid as standard, according to procedures reported elsewhere (Tavčar Benković et al. 2017; Eichhorn et al. 2017). Briefly, $2.0 \mathrm{~mL}$ of the diluted sample extract $(10 \mathrm{mg} / \mathrm{mL})$ was transferred to a tube containing $5.0 \mathrm{~mL}$ of a $1 / 10$ dilution of folin-ciocalteu's reagent in water. Then, $4.0 \mathrm{~mL}$ of a sodium carbonate solution $(7.5 \% \mathrm{w} / \mathrm{v})$ was added, and the mixture was allowed to stand at room temperature for $60 \mathrm{~min}$ before measuring the absorbance at
$765 \mathrm{~nm}$. The TPC was expressed as gallic acid equivalents (GAE) in $\mathrm{g} / 100 \mathrm{~g}$ material. The concentration of the phenols in samples was calculated from a standard curve of gallic acid ranging from 10 to $50 \mu \mathrm{g} / \mathrm{mL}$.

Determination of the free radical scavenging activity by the1,1-Diphenyl-2-picrylhydrazyl

Scavenging activities of the extracts on the free radical DPPH were assayed using Blois' method (Willfor et al. 2004, 2004; Willför et al. 2003). Briefly, $0.1 \mathrm{~mL}$ of the extracts were mixed with $0.5 \mathrm{~mL}$ of a $500 \mu \mathrm{M}$ DPPH solution in absolute ethanol and $0.4 \mathrm{~mL}$ of a $0.1 \mathrm{M}$ Tris- $\mathrm{HCl}$ buffer at $\mathrm{pH}$ 7.5. The mixture was kept for $20 \mathrm{~min}$ in darkness, and then absorbance was recorded at $515 \mathrm{~nm}$ using a mini UV-Vis spectrometer (Uvikon XL, Bio-Tek Instruments, Bad Friedrichshall, Germany). The decreased percentage of DPPH was calculated by measuring the absorbance of the sample according to the following equation:

$$
\text { Inhibition } \left.(\%)=\left[1-\left(A_{\mathrm{s}} / A_{0}\right)\right] \times 100\right]
$$

where, $A_{\mathrm{s}}$ is the absorbance of extracts, and $A_{0}$ is the absorbance of the DPPH solution.

\section{$\mathrm{Fe}^{2+}$ chelating activity}

The chelating activity $(C h A)$ of the extracts toward ferrous ions was determined as described in the literature (Pietarinen et al. 2006). Ferrous chloride ( $50 \mu \mathrm{L}, 0.25 \mathrm{mM}$ ) was added to the $150 \mu \mathrm{L}$ ethanolic solution of the extracts, and the reaction was initiated by adding ferrozine solution $(100 \mu \mathrm{L}, 1.0 \mathrm{mM})$. Absorbance at $562 \mathrm{~nm}$ (Uvikon XL, BioTek Instruments, Bad Friedrichshall, Germany) was recorded after $10 \mathrm{~min}$ of incubation at room temperature. A reaction mixture containing ethanol $(150 \mu \mathrm{L})$ instead of substance solution was used as a control. The chelating activity was calculated using the following equation:

$\mathrm{Fe}^{2+}$ Chelating Activity (\%) $=\left[1-\left(A \mathrm{~s} / A_{0}\right)\right] \times 100$ where, $A_{0}$ is the ethanol solution without test sample and $A_{\mathrm{s}}$ is the absorbance of the extract solution.

\section{GC-MS analysis}

Gas chromatography-mass spectrometry (GC-MS) analysis of silylated extracts was performed using an Agilent technologies $6890 \mathrm{~N}$ gas chromatograph equipped with HP-5MS capillary column (30 m, $0.25 \mathrm{~mm}$ i.d., 0.25 $\mu \mathrm{m}$ film thickness) coupled to a $5973 \mathrm{~N}$ mass selective detector (Agilent Technologies, Santa Clara, CA, USA). Oven temperature programmed from $60{ }^{\circ} \mathrm{C}$ for $1 \mathrm{~min}$, increased to $300{ }^{\circ} \mathrm{C}$ at $6{ }^{\circ} \mathrm{C} / \mathrm{min}$, kept at $300^{\circ} \mathrm{C}$ for $10 \mathrm{~min}$. Helium was used as carrier gas at a constant flow of 1 $\mathrm{ml} / \mathrm{min}$. The initial head pressure was 8.13 psi; injector temperature: $280{ }^{\circ} \mathrm{C}$; injection mode: split mode at a split ratio of 1:50; volume injected $1 \mu$; detector temperature: 230 ${ }^{\circ} \mathrm{C}$. MS conditions: ion source temperature: $230^{\circ} \mathrm{C}$; electron impact (EI) ionization energy: $70 \mathrm{eV}$; acquisition mode: scan (m/z 30-500); MS interface temperature $280{ }^{\circ} \mathrm{C}$. Bioactive phenols were identified using Wiley and NIST libraries. The preparation and analysis protocol of the extracts is illustrated in Fig. 2. 


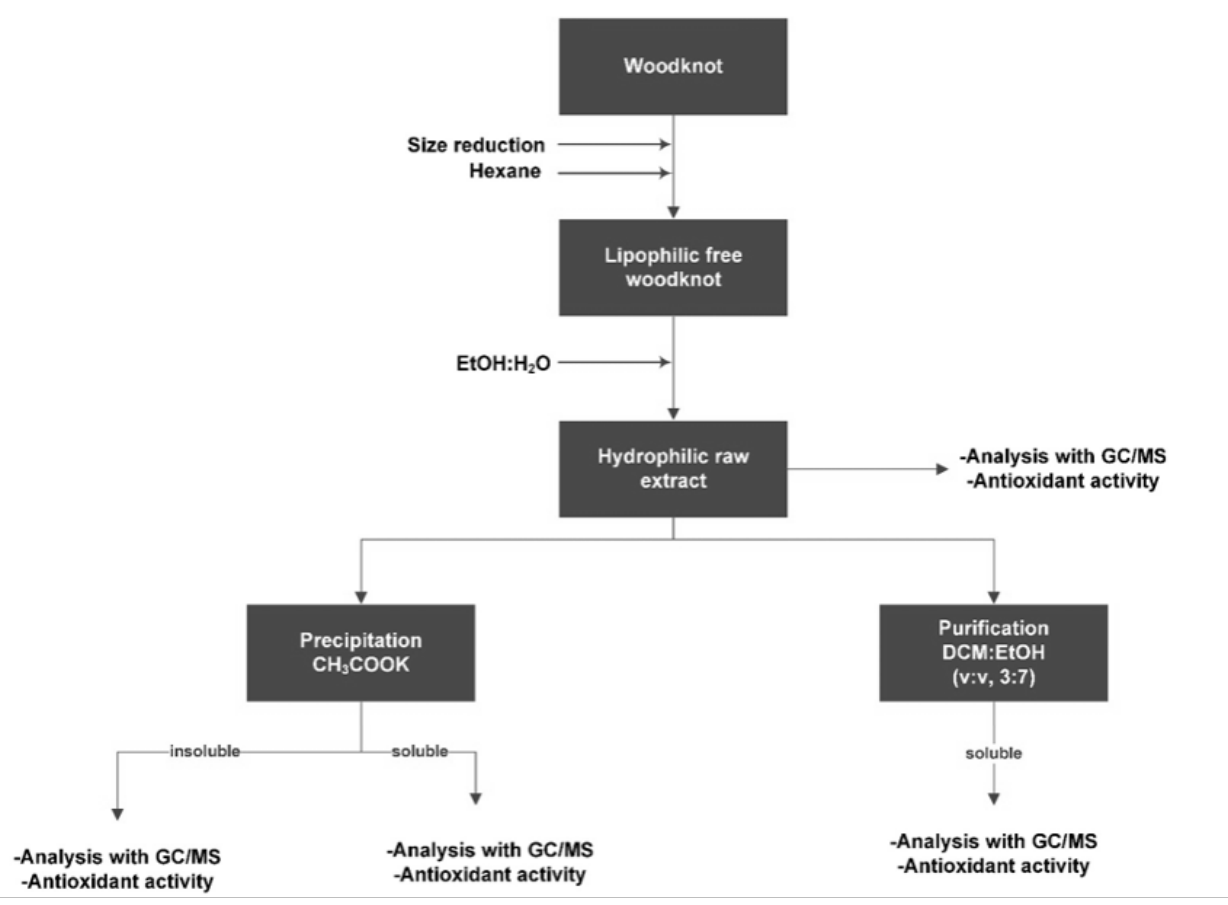

Fig. 2. Protocol for preparation and analysis of the extracts.

\section{RESULTS AND DISCUSSION}

\section{Composition of raw extracts}

The total gravimetric yield of hydrophilic extractives for Cupressus arizonica, Cupressus sempervirens and Picea excelsa wood knot was determined in the range of 1.6-2.48 (w/w). The GC-FID chromatograms of silylated $C$. arizonica, C. sempervirens and $P$. excelsa wood knot EtOH raw extract are shown in Fig. 3. The identity, relative retention time, and yield of each compound in the raw EtOH extract are presented in Table 1. The identification was done according to the interpretation of GC-MS analysis giving almost correct relative peak abundances of bioactive phenols (Sedaghat, Abdolkhani, and Khodaiyan chegini 2015). The contribution of matairesinol (MAT) in the EtOH extract of C. arizonica wood knot was $11.3 \%$. Dienestrol was the second most abundant lignan with a contribution of only $0.4 \%$. Curcumin, an active diarylheptanoid, was identified with $0.9 \%$ in C. arizonica wood knot. All the other lignans in the extract were in minor quantity compared to MAT.

Matairesinol was the main lignin component of the $C$. sempervirens which is $8.2 \%$ of total moieties. The total contribution of the lignans in $P$. excels $a$ was determined as $33.37 \%$ of the raw EtOH extract. $\alpha$-conidendrin was the principal component of the $P$. excelsa extract with a contribution of $23.24 \%$. Nortrachelogenin (NTG) was the second most abundant lignan with a contribution of $4.49 \%$, followed by matairesinol, dihydroconiferyl alcohol, and secoisolariciresinol, a contribution of 3.64, 1.66, and $0.34 \%$, respectively. The chemical structure of the identified moieties in three species is shown in Fig. 4.

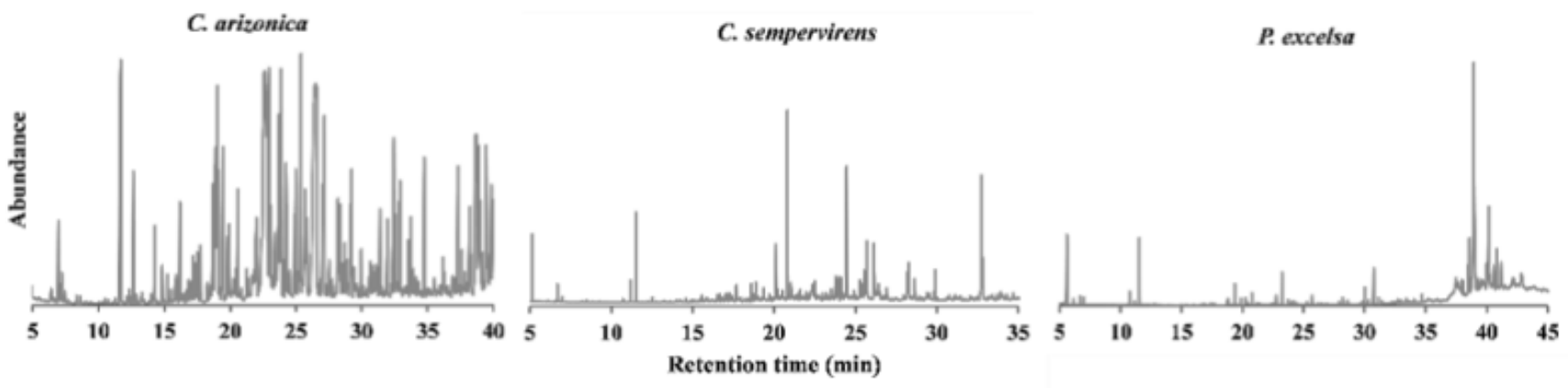

Fig. 3. Gas chromatograph of raw ethanolic extract from C. arizonica, C. sempervirens, and P. excelsa wood knot. 
Table 1. Main component groups and compounds in the raw hydrophilic wood knot.

\begin{tabular}{|c|c|c|c|c|c|}
\hline $\begin{array}{l}\text { Composition } \\
\text { (\% of gravimetric extract) }\end{array}$ & Category & Subcategory & C. arizonica & C.sempervirens & P. excelsa \\
\hline Sugars & & & 17.96 & 19.04 & \\
\hline Fatty acid & & & 3.19 & 8.9 & 2.67 \\
\hline Waxes & & & & 3.3 & 1.99 \\
\hline \multirow[t]{2}{*}{ Terpenoids } & Resin acids & & 0.2 & 1.1 & 2.22 \\
\hline & others & & 1.04 & 0.1 & 1.51 \\
\hline Steroids & & & 0.6 & 4.9 & \\
\hline Alkaloids & & & 0.1 & 0.5 & \\
\hline Aromatic monomers & & & 6.2 & 6.9 & \\
\hline Aromatic Compounds & & & 12.4 & 2.1 & 43.59 \\
\hline \multirow[t]{2}{*}{ Bioactive phenolic monomers } & Bioactive phenolic & & 3.23 & 13.5 & 3.9 \\
\hline & others & & 6.08 & 11.3 & 6.03 \\
\hline Quinones & & & & 0.5 & \\
\hline \multirow[t]{12}{*}{ Bioactive phenolic compounds } & Lignans & & 11.7 & 8.2 & 33.37 \\
\hline & & Matairesinol & 11.3 & 8.2 & 3.64 \\
\hline & & Secoisolariciresinol & & & 0.34 \\
\hline & & Nortrachelogenin & & & 4.49 \\
\hline & & Dihydro diconiferyl alcohol & & & 1.66 \\
\hline & & $\alpha$-Conidendrin & & & 23.24 \\
\hline & & Dinosterol & 0.4 & & \\
\hline & Flavonoids & & & & \\
\hline & Stilbenes & & & & \\
\hline & Tannins & & & & \\
\hline & diarylheptanoid & & 0.9 & & \\
\hline & others & & & & 5.7 \\
\hline
\end{tabular}

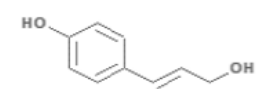

(1)<smiles>COc1cc(C(O)CN)ccc1O</smiles>

(4)

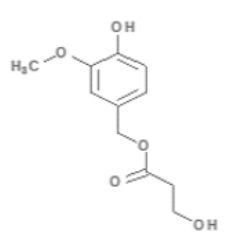

(7)

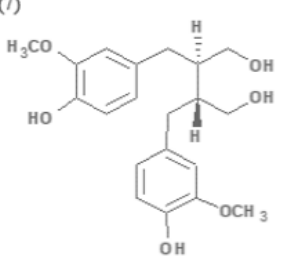

(10)

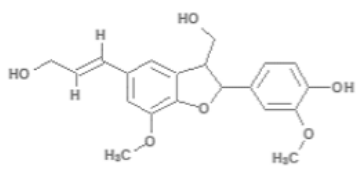

(12)

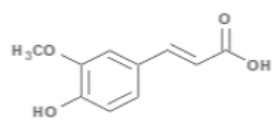

(2)
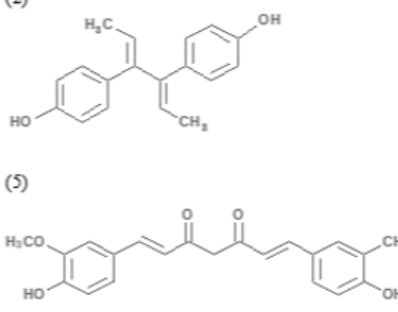

(8)

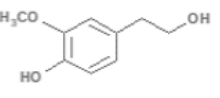

(3)

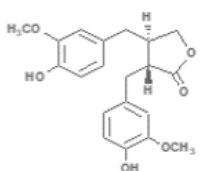

(6)

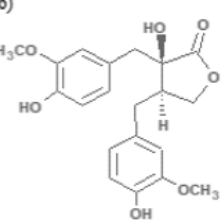

(9)

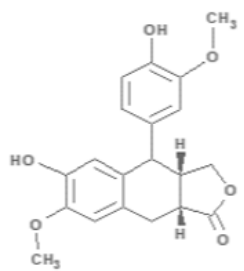

(11)

Fig. 4. Structure of the phenolic compounds identified in wood knots. 
Table 2. Main bioactive phenolic compounds of wood knots (structures as illustrated in Fig. 4).

\begin{tabular}{llc}
\hline Wood species & Composition & $\begin{array}{r}\text { Retention } \\
\text { time (min) }\end{array}$ \\
\hline Cupressus & Paracoumaryl alcohol (1) & 21.74 \\
& Ferulic Acid (2) & 31.01 \\
& Dienestrol (5) & 32.90 \\
& Normetanephrine (4) & 33.74 \\
& diarylheptanoid curcumin & 37.30 \\
& (8) & \\
& matairesinol (MAT) (6) & 40.38 \\
Cupressus & Homovanillyl alcohol (3) & 43.46 \\
sempervirens & matairesinol (MAT) (6) & 40.11 \\
& & \\
& methyl vinyl lactate Bis- & 41.24 \\
Picea excelsa & hydroxy ether (7) & \\
& Secoisolariciresinol (SEC) & 38.42 \\
& (10) & 39.52 \\
& matairesinol (MAT) (6) & 40.09 \\
& Nortrachelogenin (NTG) \\
& (9) & \\
& dihydro diconiferyl alcohol & 40.56 \\
& (12) & \\
& Conidendrin (11) & 41.43 \\
\hline
\end{tabular}

\section{Purification of wood knot ethanolic extract}

Two different protocols were used to purify the phenolics from the raw ethanolic essence of $C$. arizonica. In the first route, the ethanolic raw extract was purified by thin-layer chromatography (TLC) using dichloromethane: ethanol (DCM:EtOH, 10:1, v:v) as the eluent. Moreover, potassium acetate was added to the raw ethanolic extract to precipitate the phenolic-rich fractions. The output of these two procedures characterized by gas chromatography is illustrated in Fig. 5.
The overall composition of the extract after TLC purification indicates the elimination of sugar impurities from ethanolic extract (Table 3). The amount of matairesinol (MAT) was increased to $16.38 \%$ in the purified sample. Fig. 5 indicates that precipitation with potassium acetate is more effective in bioactive phenolic purification than the TLC method. The contribution of matairesinol in precipitates of potassium acetate and its relative supernatant was determined 32.59 and $40.44 \%$, respectively.

\section{Total phenolic content by folin-ciocalteau method}

Total phenolic content (TPS) of raw and purified isolated extracts from wood knots was standardized for their phenolic content by the folin-ciocalteau method. The total phenolic content was calculated as gallic acid equivalent (GAE). The calibration test showed a linear correlation for gallic acid in the concentration range of $0.2-1 \mathrm{mg} \mathrm{ml}^{-1}$ $\left(\mathrm{R}^{2}=0.99\right)$. The total phenolic content of purified and unpurified extracts is shown in Fig. 6.

The $P$. excelsa with a total capacity of $318.8 \mathrm{mg}^{-\mathrm{ml}^{-1}}$ showed the highest level of phenolics, followed by unpurified C. arizonica $\left(257.5 \mathrm{mg} \cdot \mathrm{ml}^{-1}\right)$ and the solvent purified extract of $C$. arizonica $\left(190.1 \mathrm{mg}^{-\mathrm{ml}^{-1}}\right)$. The total phenolic capacity of raw extracts was decreased upon purification with different methods since parts of the phenolic moieties were excluded during the purification process. According to the GC-MS analysis, the phenolic acids are the main removed compounds in purified extracts. The contribution of phenolic acids decreased from 3.23 to 0.98 , and $0.81 \%$ in unpurified and potassium acetate and TLC purified extracts in C. arizonica, respectively (Table $3)$.

Table 3. Main component groups and compounds in the EtOH extracts and fractions of extracts from C. arizonica wood knot.

\begin{tabular}{|c|c|c|c|c|c|c|}
\hline $\begin{array}{l}\text { Composition } \\
\text { (\% of gravimetric extract) }\end{array}$ & Category & Subcategory & $\begin{array}{l}\text { Unpurified } \\
\text { C. arizonica }\end{array}$ & $\begin{array}{c}\text { Precipitated } \\
\text { with } \\
\mathrm{CH}_{3} \mathrm{COOK}\end{array}$ & $\begin{array}{c}\text { Purified } \\
\text { with } \\
\mathrm{CH}_{3} \mathrm{COOK} \\
\end{array}$ & $\begin{array}{l}\text { Purified with } \\
{ }^{\text {aTLC }}\end{array}$ \\
\hline Sugars & & & 17.96 & 1.57 & 4.95 & \\
\hline Aromatic compounds & & & 6.2 & & 6.89 & 0.76 \\
\hline \multirow[t]{2}{*}{ Phenolic monomers } & $\begin{array}{l}\text { Bioactive phenolic } \\
\text { acids }\end{array}$ & & 3.23 & & 0.98 & 0.81 \\
\hline & others & & 6.08 & 5.07 & 8.69 & 4.46 \\
\hline \multirow{6}{*}{$\begin{array}{l}\text { Bioactive phenolic } \\
\text { compounds }\end{array}$} & Lignans & & 11.7 & 34.61 & 41.21 & 17.13 \\
\hline & & $\begin{array}{l}\text { matairesinol } \\
\text { (MAT) (6) }\end{array}$ & 11.3 & & & 16.38 \\
\hline & & $\begin{array}{l}\text { arctigenin } \\
\text { (ARC) (13) }\end{array}$ & & 32.59 & 40.44 & 0.75 \\
\hline & & $\begin{array}{l}\text { Secoisolaricire } \\
\text {-sinol (SEC) } \\
(10)\end{array}$ & & 2.01 & 0.76 & \\
\hline & & Dienestrol (5) & 0.4 & & & \\
\hline & $\begin{array}{l}\text { Stilbenes } \\
\text { diarylheptanoid }\end{array}$ & & 0.9 & & & 0.4 \\
\hline
\end{tabular}

\footnotetext{
a Thin Layer Chromatography
} 


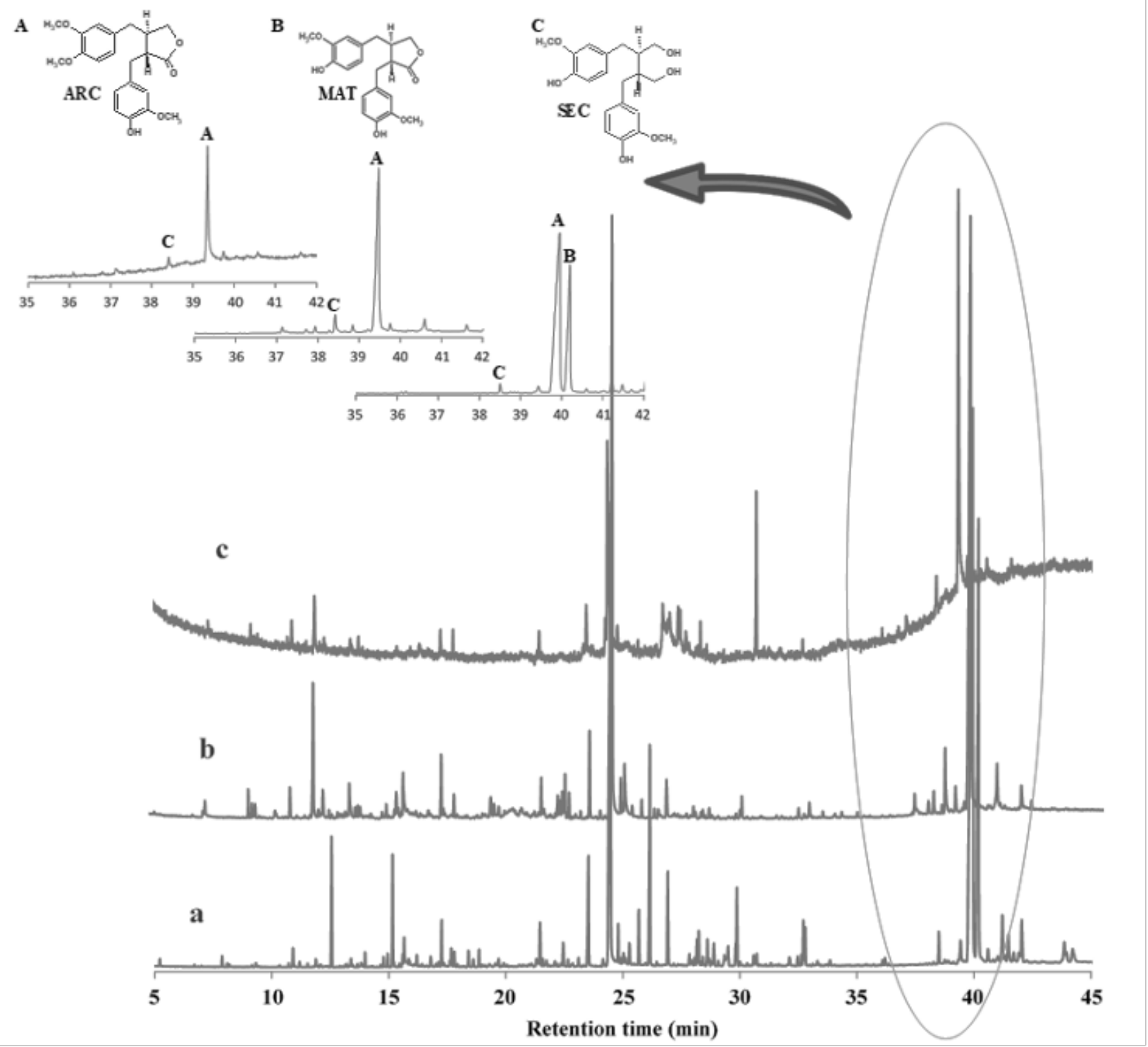

Fig. 5. Gas chromatogram of EtOH extract from C. arizonica knot. (a) Purified with TLC (b) Purified with $\mathrm{CH}_{3} \mathrm{COOK}$ (c) Precipitated with $\mathrm{CH}_{3} \mathrm{COOK}$.

\section{DPPH radicals scavenging and iron (II) chelating capacity}

The antioxidant activity of the different extracts was determined with DPPH (2,2-diphenyl-1-picrylhydrazyl) radical scavenging assay (Fig. 7). Butylated hydroxyanisole (BHA) was used as the standard to compare the radical scavenging activities.

The most powerful radical scavenging activity was a raw ethanolic extract from P.excelsa wood knot with $66.67 \%$, followed by BHA and potassium acetate purified C. arizonica with 57.96 and $56.37 \%$, respectively. The DPPH inhibition activity of moieties present in precipitated potassium acetate was only $14.66 \%$. No relationship between phenolic compound contents and the inhibition rate of DPPH radical was observed in different species; since, in addition to phenolics, other compounds (e.g. terpenoids) may also have radical scavenging activity. It has been reported that the antioxidant activity of phenolic compounds depends on the number and location of hydroxyl groups in the phenolic compounds (Sok, Cui, and Kim 2009). The ability of the different extracts from wood knots in chelating ferrous ions was illustrated in Fig. 8. Purified $(C$. arizonica) and unpurified $(C$. arizonica, $C$. sempervirens) ethanolic extracts (concentration: $2 \mathrm{mg} \mathrm{ml}^{-1}$ ) completely chelated ferrous ions, whereas $P$. excelsa extract exhibit a low chelating capacity with an amount of $19.59 \%$. Depending on the quality and quantity of extracted moieties with ethanol, ferrous ion's chelating affinity differs in various species (Belt, Hanninen, and Rautkari 2017; Wijayanto et al. 2015). 


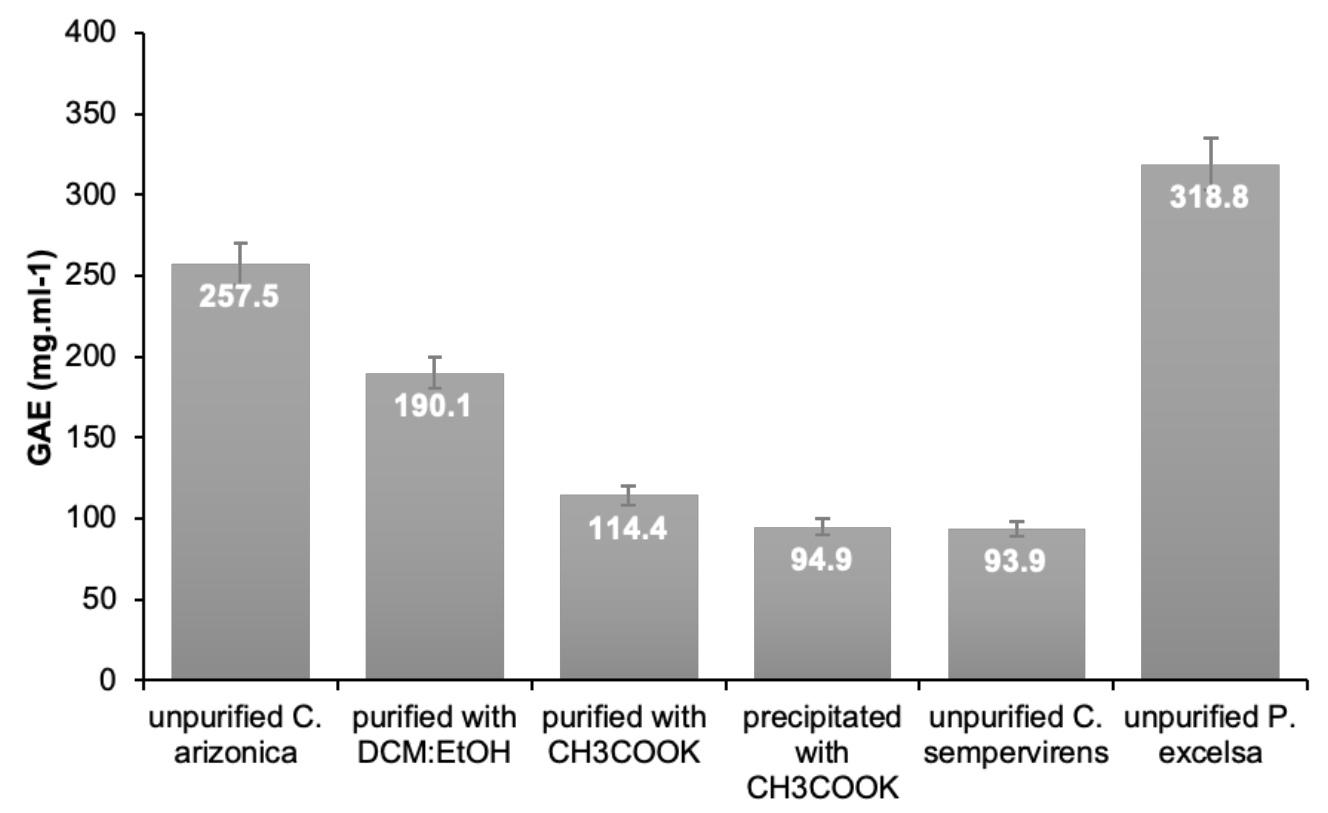

Fig. 6. Total phenolic content of purified and unpurified ethanolic extracts.

\section{CONCLUSION}

The study of the ethanolic extracts of wood knot from $C$. arizonica, $C$. sempervirens and $P$. excelsa with ethanol: $\mathrm{H}_{2} \mathrm{O}$ indicated the presence of different bioactive phenols. Matairesinol (MAT) and dienestrol (DIN) was the predominant lignans in ethanolic extract of $C$. arizonica wood knot. Matairesinol (MAT) was the main component of $C$. sempervirens wood knot extract. Matairesinol (MAT), secoisolariciresinol (SEC), nortrachelogenin (NTG), dihydro diconiferyl alcohol and conidendrin were the main identified bioactive phenols in $P$. exselsa wood knot. Purification with TLC using dichloromethane:ethanol effectively excluded sugars impurities from raw ethanolic extract. Addition of potassium acetate to C. arizonica raw ethanolic extract led to an increase in the contribution of matairesinol (MAT) and arctigenin (ARC). In addition to phenolic compounds, other moieties in ethanolic caused an increase in total radical scavenging activity.

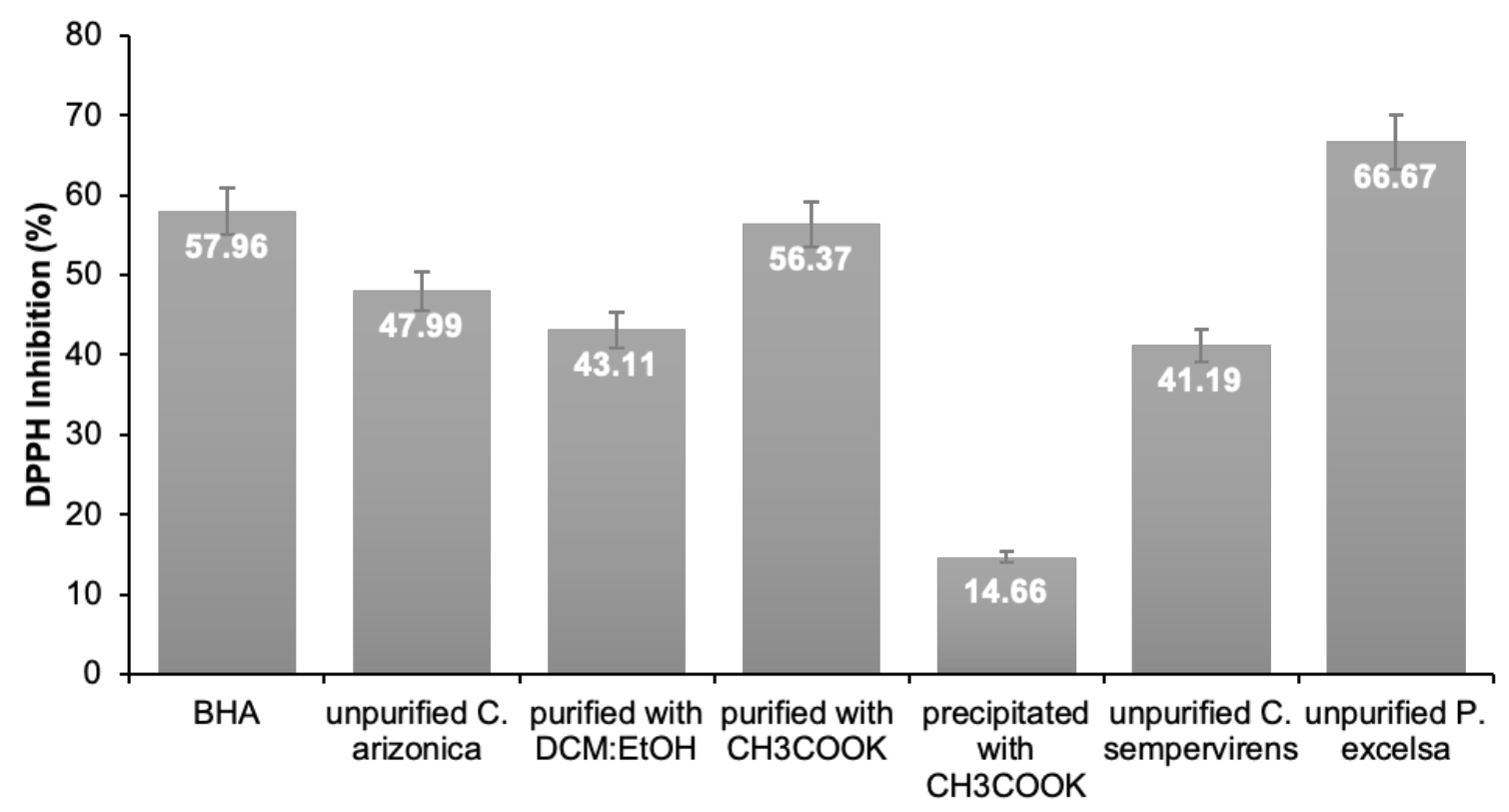

Fig. 7. Free DPPH radical scavenging potency of purified and unpurified extracts (DPPH concentration: $0.5 \mathrm{mg} / \mathrm{ml}$ ). 


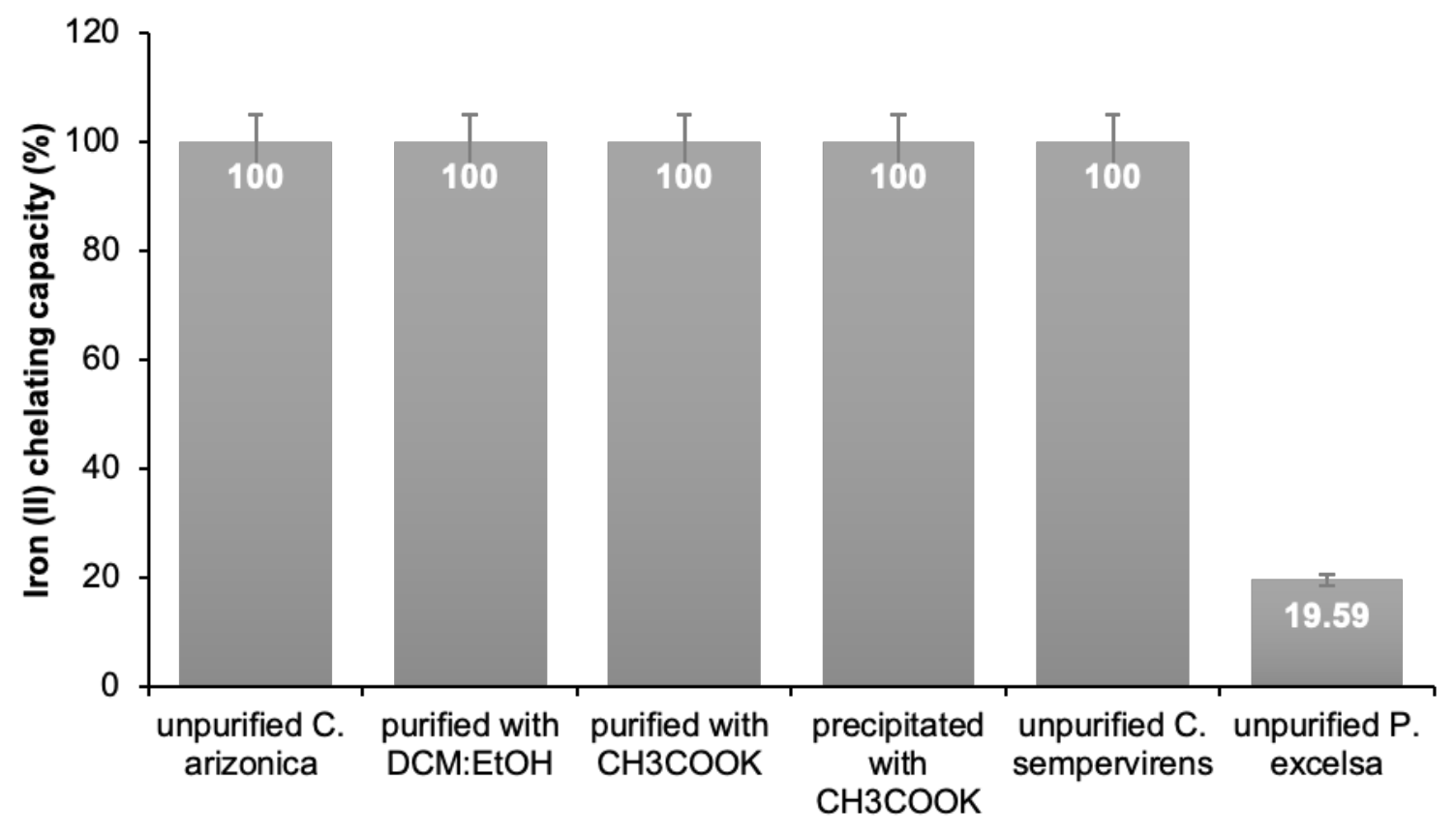

Fig. 8. Iron (II) chelating capacity assay of purified and unpurified extracts (Ferrous concentration: 2 mg/ml).

\section{REFERENCES}

Aranda, I., D. Sánchez-Gómez, E. Cadahía and B.F. de Simón. 2018. Ecophysiological and metabolic response patterns to drought under controlled condition in openpollinated maternal families from a Fagus sylvatica L. population. Environmental and Experimental Botany 150:209-221.

https://doi.org/10.1016/j.envexpbot.2018.03.014

Belt, T., T. Hanninen and L. Rautkari. 2017. Antioxidant activity of Scots pine heartwood and knot extractives and implications for resistance to brown rot. Holzforschung 71:527-534. https://doi.org/10.1515/hf2016-0232

Bhaskar, T., J.S. Chang, S. Khanal, D.J. Lee, S. Venkata Mohan and B.E. Rittmann. 2016. Waste Biorefinery Advocating Circular Economy. Bioresource Technology 215:1. https://doi.org/10.1016/j.biortech.2016.06.020

Conde, E., W.W. Fang, J. Hemming, S. Willfor, H. Dominguez and J.C. Parajo. 2014. Recovery of bioactive compounds from Pinus pinaster wood by consecutive extraction stages. Wood Science and Technology 48:311-323. https://doi.org/10.1007/s00226-013-0604-1

Cosentino, M., F. Marino, M. Ferrari, E. Rasini, R. Bombelli, A. Luini, M. Legnaro, M.G.D. Canne, M. Luzzani, F. Crema, S. Paracchini and S. Lecchini. 2007. Estrogenic activity of 7-hydroxymatairesinol potassium acetate (HMR/lignan ${ }^{\mathrm{TM}}$ ) from Norway spruce (Picea abies) knots and of its active metabolite enterolactone in MCF-7 cells. Pharmacological Research 56:140-147. https://doi.org/10.1016/j.phrs.2007.05.001
Da Silva, J.A.T., L. Yonekura, J. Kaganda, J. Mookdasanit, D.T. Nhut and G. Afach. 2005. Important Secondary Metabolites and Essential Oils of Species Within the Anthemideae (Asteraceae). Journal of Herbs, Spices \& Medicinal Plants 11:1-46. https://doi.org/10.1300/J044v11n01_01

Eichhorn, S., S. Erfurt, T. Hofmann, S. Seegmuller, R. Nemeth and F. Hapla. 2017. Determination of the Phenolic Extractive Content in Sweet Chestnut (Castanea Sativa Mill.) Wood. Wood Research 62:181196.

Hillis, W.E. 1971. Distribution, Properties and Formation of Some Wood Extractives. Wood Science and Technology 5:272-\&. https://doi.org/10.1007/BF00365060

Hillis, W.E. and T. Inoue. 1968. The formation of polyphenols in trees-IV: The polyphenols formed in Pinus radiata after Sirex attack. Phytochemistry 7:1322. https://doi.org/10.1016/S0031-9422(00)88199-6

Holmbom, B., S. Willfoer, J. Hemming, S. Pietarinen, L. Nisula, P. Eklund and R. Sjoeholm. 2007. Knots in Trees: A Rich Source of Bioactive Polyphenols. Materials, Chemicals, and Energy from Forest Biomass 954:350-362. https://doi.org/10.1021/bk2007-0954.ch022

Im, S.J., J.H. Kim and M.Y. Kim. 2014. Evaluation of bioactive components and antioxidant and anticancer properties of citrus wastes generated during bioethanol production. Natural Product Communications 9:483486. https://doi.org/10.1177/1934578X1400900413

Jonsson, M.B., F. Aldaeus, A. Reimann, P. Ljungquist, H. Schweinebarth and M. Boklund. 2011. Extraction of Bioactive Chemicals in Spruce Wood Residues. 16th 
International Symposium on Wood, Fiber and Pulping Chemistry, Proceedings, Vols I \& Ii:117-119.

Kamm, B., P. Schonicke and C. Hille. 2016. Green biorefinery - Industrial implementation. Food Chemistry 197:1341-1345.

https://doi.org/10.1016/j.foodchem.2015.11.088

Kebbi-Benkeder, Z., F. Colin, S. Dumarçay and P. Gérardin. 2015. Quantification and characterization of knotwood extractives of 12 European softwood and hardwood species. Annals of Forest Science 72:277284. https://doi.org/10.1007/s13595-014-0428-7

Langeveld, J.W.A., J. Dixon and J.F. Jaworski. 2010. Development perspectives of the biobased economy: A review. Crop Science 50:S-142-S-151. https://doi.org/10.2135/cropsci2009.09.0529

Liu, J., S. Willför and C. Xu. 2015. A review of bioactive plant polysaccharides: Biological activities, functionalization, and biomedical applications. Bioactive Carbohydrates and Dietary Fibre 5:31-61. https://doi.org/10.1016/j.bcdf.2014.12.001

Miki, K., T. Takehara, T. Sasaya and A. Sakakibara. 1980. Lignans of Larix leptolepis. Phytochemistry 19:449453. https://doi.org/10.1016/0031-9422(80)83199-2

Peralta, R.M., E.A. Koehnlein, R.F. Oliveira, V.G. Correa, R.C.G. Corrêa, L. Bertonha, A. Bracht and I.C.F.R. Ferreira. 2016. Biological activities and chemical constituents of Araucaria angustifolia: An effort to recover a species threatened by extinction. Trends in Food Science \& Technology 54:85-93. https://doi.org/10.1016/j.tifs.2016.05.013

Phelan, M., S.A. Aherne, A. Wong and N.M. O'Brien. 2009. Bioactive Properties of Wood Knot Extracts on Cultured Human Cells. Journal of Medicinal Food 12:1245-1251. https://doi.org/10.1089/jmf.2008.0125

Pietarinen, S., J. Hemming, S. Willfor, F. Vikstrom and B. Holmbom. 2005a. Wood resin in bigtooth and quaking aspen wood and knots. Journal of Wood Chemistry and Technology 25:27-39. https://doi.org/10.1081/WCT200058235

Pietarinen, S.P., S.M. Willför, M.O. Ahotupa, J.E. Hemming and B.R. Holmbom. 2006. Knotwood and bark extracts: Strong antioxidants from waste materials. Journal of Wood Science 52:436-444. https://doi.org/10.1007/s10086-005-0780-1

Pietarinen, S.P., S.M. Willför, R.E. Sjöholm and B.R. Holmbom. 2005b. Bioactive phenolic substances in important tree species. Part 3: Knots and stemwood of Acacia crassicarpa and A. mangium. Holzforschung 59:94-101. https://doi.org/10.1515/HF.2005.015

Sedaghat, A., A. Abdolkhani and F. Khodaiyan chegini. 2015. Extraction and purification matairesinol bioactive lignan of arizonica cypress (Cupressus arizonica). Iranian Journal of Wood and Paper Industries 6:325-331.
Sergio, L., A. Cardinali, A. De Paola and D. Di Venere. 2009. Biochemical properties of soluble and bound peroxidases from artichoke heads and leaves. Food Technology and Biotechnology 47:32-38.

Sharma, D.K., A.K. Pandey and Lata. 2009. Use of Jatropha curcas hull biomass for bioactive compost production. Biomass and Bioenergy 33:159-162.

https://doi.org/10.1016/j.biombioe.2008.05.002

Sok, D.E., H.S. Cui and M.R. Kim. 2009. Isolation and boactivities of furfuran type lignan compounds from edible plants. Recent Patents on Food, Nutrition and Agriculture 1:87-95. https://doi.org/10.2174/2212798410901010087

Tavčar Benković, E., D. Žigon, V. Mihailović, T. Petelinc, P. Jamnik and S. Kreft. 2017. Identification, in vitro and in vivo Antioxidant Activity, and Gastrointestinal Stability of Lignans from Silver Fir (Abies alba) Wood Extract. Journal of Wood Chemistry and Technology 37:467-477. https://doi.org/10.1080/02773813.2017.1340958

Valette, N., T. Perrot, R. Sormani, E. Gelhaye and M. Morel-Rouhier. 2017. Antifungal activities of wood extractives. Fungal Biology Reviews 31:113-123. https://doi.org/10.1016/j.fbr.2017.01.002

Wijayanto, A., S. Dumarcay, C. Gerardin-Charbonnier, R.K. Sari, W. Syafii and P. Gerardin. 2015. Phenolic and lipophilic extractives in Pinus merkusii Jungh. et de Vries knots and stemwood. Industrial Crops and Products 69:466-471. https://doi.org/10.1016/j.indcrop.2015.02.061

Willfor, S., L. Nisula, J. Hemming, M. Reunanen and B. Holmbom. 2004. Bioactive phenolic substances in industrially important tree species. Part 1: Knots and stemwood of different spruce species. Holzforschung 58:335-344. https://doi.org/10.1515/HF.2004.052

Willfor, S. 2004. Bioactive phenolic substances in industrially important tree species. Part 2: Knots and stemwood of fir species. Holzforschung 58:650-659. https://doi.org/10.1515/HF.2004.119

Willför, S.M., M.O. Ahotupa, J.E. Hemming, M.H.T. Reunanen, P.C. Eklund, R.E. Sjöholm, C.S.E. Eckerman, S.P. Pohjamo and B.R. Holmbom. 2003. Antioxidant Activity of Knotwood Extractives and Phenolic Compounds of Selected Tree Species. Journal of Agricultural and Food Chemistry 51:76007606. https://doi.org/10.1021/jf030445h

Zhang, X., M. Tu, M. Paice, G. Sacciadis, Z. Jiang, N. Jemaa and A. Thibault. 2010. Bioconversion of knot rejects from a sulphite pulp mill to ethanol. Bioresources 5:23-42. 